\title{
Perception of Medical Faculty Student of Haluoleo University about Inter Professional Education
}

\author{
Haryati Haryati $^{1}$, Ashaeryanto Ashaeryanto ${ }^{2}$, La Rangki ${ }^{3}$, Eka Sardila ${ }^{4}$ \\ \{haryati.aeta2017@gmail.com ${ }^{1}$, ashaeryanto@yahoo.com², rangki1979@gmail.com ${ }^{3}$, \\ ekasardila1@gmail.com $\left.{ }^{4}\right\}$ \\ 1,2,3 Medical Faculty of Halu Oleo University, Kendari, South East of Sulawesi, Indonesia \\ ${ }^{4}$ Nursing Concentration of Medical Faculty of Halu Oleo University, Kendari, \\ South East of Sulawesi, Indonesia
}

\begin{abstract}
One effort in realizing quality and effective collaboration among health professions is the holding of early collaborative practices through learning systems by conducting Inter Professional Education in the academic stage. This study aims to identify medical student perception about interprofessional education at medical faculty of Halu Oleo University. This study was a comparative analytical research design. The number of samples were 46 respondents with used purposive sampling. Statistical analysis using non parametric Mann Withney comparative test with a 95\% CI value. The results showed that medical education study program students have a good perception of the IPE as much as $86 \%$ and the nursing concentration students have a good perception of the IPE as much as $86 \%$. The results of comparative test was obtained pvalue $=0.947$. There is no difference perceptions of Medical students of Halu Oleo University about the IPE both of students in the Medical Education Study Program and students in the Nursing Concentration.
\end{abstract}

Keyword: Interprofessional Education, Medical Students, Nursing Students, Perception

\section{Introduction}

Health professionals are required to provide quality health services to prevent errors in the treatment of patients in the hospital. Quality services can be obtained from good collaboration between professions such as doctors, nurses and pharmacists as a teamwork. One of the efforts in realizing effective collaboration between professions is the holding of collaborative practices early through the learning process, by educating health professions students using the Inter Professional Education (IPE) strategy [1].

Interprofessional education and interprofessional learning have received increased attention worldwide in the last decade as a number of patient and health services related problems may be improved by better collaboration between health professionals [2]. Collaboration between health professions in Indonesia is still far from ideal. One of the reasons for this could be due to a lack of understanding of a health profession on the competencies of other health professionals or because of a lack of communication between health professions in teamwork and collaboration. This has an impact on the ineffective and inefficient use of health services received by the community [3]. 
Inter Professional Education (IPE) occurs when two or more health professions student learn with, from, and about each other to improve collaboration skills and health service quality [4]. World Health Organization shows the results of survey of institutions from 42 countries stated that they had implemented the IPE strategy and had a positive impact on the inter-professional collaboration system in the world of health [5]. However, the development of the IPE curriculum has not been applied evenly in educational institutions [1].

In Indonesia, IPE has been used in several higher education institutions as a daily curriculum such as the University of Indonesia, Gadjah Mada University, Muhammadiyah University of Yogyakarta, and Indonesian Islamic University [6]. Based on the results of research conducted by student of Muhammadiyah University of Surakarta on the differences in the perceptions of health student towards IPE from each study program in Nursing Science Faculty showed a very positive perception of IPE. In this study it was found that the perceptions of each study program were in good categories with scores from Nursing $38.6 \%$, Pharmacy as much $34.9 \%$, and General Medical as much $26.5 \%$.

The results of the study were also supported by the results of research about the perceptions of health profession students at Padjajaran University towards IPE, which showed $98 \%$ of respondents had good perceptions. However, based on the results of research from several institutions, it shows that there are still many respondents who have less perception of IPE. Poor perceptions of the components of perceived need for cooperation are more compared to other IPE components such as components of competence and autonomy, perception of actual cooperation, and sharing of intra and inter-professional resources [6].

Students' perception and experience of interprofessional education play a relevant role in the introduction on interprofessional education and have been analysed in various programmes [2]. At the Medical Faculty of Halu Oleo University, IPE has not been implemented due to the lack of exposure to the IPE. Medicial Faculty of Halu Oleo University is divided into students of Medical Education Study Program and Nursing Science Concentration, who do not yet understand the IPE specifically. Evaluating student perception of IPE is required to guide the development of, and changes to, curricula to improve engangement with IP practice.

\section{Research Method}

This study uses a comparative analytical design with sampling techniques using purposive sampling. The sample in this study was the fourth years students of Medical Faculty of Halu Oleo University, which consisted of students from the Medical Education Study Program and Nursing Science Concentration, with a total sample of 46 samples. Statistical analysis using non parametric Mann Withney comparative test with a $95 \%$ CI value.

The instrument that used in this study was the Interdisciplinary Education Perception Scale (IEPS) questionnaire developed by Luchet et al in 1990. In this questionnaire there are 18 item statements, but in 2007, Mc Fadyen has modified it by removing several statement items into 12 statement items with three subscales were: competence and autonomy, perceived need for cooperation; and perception of actual cooperation [7]. Some of the items removed are items that cannot be applied to students who have not undergone the clinical phase so that the validity is better. 


\section{Results and Discussion}

3.1 Characteristics of Respondents and Perception of Medical Student of Halu Oleo University on IPE

Tabel 1. Characteristics of Respondents based on Gender and Study Program.

\begin{tabular}{ccc}
\hline Characteristics & Amount (n) & Percentage (\%) \\
\hline Gender & 8 & 17.4 \\
Male & 38 & 82.6 \\
Female & $\mathbf{4 6}$ & $\mathbf{1 0 0}$ \\
\hline Total & & 50.0 \\
\hline Study Program & 23 & 50.0 \\
Medical student & 23 & $\mathbf{1 0 0}$ \\
Nursing student & $\mathbf{4 6}$ & \\
\hline Total & &
\end{tabular}

Based on table 1 it was found that the number of male respondents was 8 respondents $(17.4 \%)$ and femaleas many as 38 respondents $(82.6 \%)$. The number of respondents based on the study program categories is Medical Education amounted to 23 respondents $(50 \%)$ and Nursing Sciences amounted to 23 respondents (50\%).

Table 2. The Perception of Medical Faculty Students of Halu Oleo University about Interprofessional Education.

\begin{tabular}{lccc}
\hline & Categories & Amount (n) & Percentage (\%) \\
\hline Good & & 45 & 98 \\
Poor & & 1 & 2 \\
\hline & Total & $\mathbf{4 6}$ & $\mathbf{1 0 0}$ \\
\hline
\end{tabular}

Table 2 shows that most of students of the Medical Faculty of Halu Oleo University have good perceptions of IPE with a good category of 45 people (98\%).

Table 3. The Perception Category of Medical Faculty Students of Halu Oleo University based on the Score of the IPE component.

\begin{tabular}{|c|c|c|c|c|}
\hline $\begin{array}{c}\text { Study } \\
\text { Program }\end{array}$ & IPE components & $\begin{array}{c}\text { Perception } \\
\text { Category }\end{array}$ & $\begin{array}{l}\text { Amount } \\
\text { (n) }\end{array}$ & Percentage $(\%)$ \\
\hline \multirow{6}{*}{$\begin{array}{l}\text { Medical } \\
\text { Student }\end{array}$} & Competence and & Good & 23 & 100 \\
\hline & Autonomy & Poor & 0 & 0 \\
\hline & \multirow{2}{*}{$\begin{array}{l}\text { Perceived need for } \\
\text { cooperation }\end{array}$} & Good & 23 & 100 \\
\hline & & Poor & 0 & 0 \\
\hline & \multirow{2}{*}{$\begin{array}{l}\text { Perception of actual } \\
\text { cooperation }\end{array}$} & Good & 23 & 100 \\
\hline & & Poor & 0 & 0 \\
\hline \multirow{6}{*}{$\begin{array}{l}\text { Nursing } \\
\text { Student }\end{array}$} & \multirow{2}{*}{$\begin{array}{l}\text { Competence and } \\
\text { Autonomy }\end{array}$} & Good & 23 & 100 \\
\hline & & Poor & 0 & 0 \\
\hline & \multirow{2}{*}{$\begin{array}{l}\text { Perceived need for } \\
\text { cooperation }\end{array}$} & Good & 23 & 100 \\
\hline & & Poor & 0 & 0 \\
\hline & \multirow{2}{*}{$\begin{array}{l}\text { Perception of actual } \\
\text { cooperation }\end{array}$} & Good & 23 & 100 \\
\hline & & Poor & 0 & 0 \\
\hline
\end{tabular}


Table 3 shows that the perceptions of students of the Medical Education Study Program and Nursing Science Concentration about IPE based on the score of each component of the IPE found that all respondents $(100 \%)$ had good perceptions.

\subsection{Difference in Perception of Medical Faculty Students of Halu Oleo University about Interprofessional Education}

Tabel 4. Difference in Perception of Medical Faculty Students of Halu Oleo University about Interprofessional Education.

\begin{tabular}{cccc}
\hline Groups & n & Mean Ranks & P value \\
\hline Medical Student & 23 & 23.63 & \\
Nursing Student & 23 & 23.37 & 0.947 \\
\hline
\end{tabular}

Table 4 shows the results of the study after using the Mann Withney test showing that the result is 0.947 , where the $\mathrm{p}$ value $>0.05$. Based on the results obtained meaning that there is no difference in perception about IPE by students of the Medical Education Study Program and Nursing Science Concentration students at the Medicine Faculty of Halu Oleo University.

Students' perception toward interprofessional education are important factors that affect their acceptance of this approach to education. Evaluation of student perceptions of IPE and practice can provide an insight into their willingness to engange with, or identify barriers to engangement with, IP practice [7]. The IEPS is considered to be a measure of attitudes and perceptions of the interprofessional experience [5].

The results of the study showed that $98 \%$ of students at the Medical Faculty of Halu Oleo University have a good perception of IPE. The results of the analysis on the perception category based on the score of the IPE component showed that all respondents $(100 \%)$ from the Medical Education Study Program and Nursing Science Concentration showed good perceptions. The results of this study are consistent with studies conducted by Olenick et al. and Lairamore et al., which showed that most healthcare students had a positive perception of IPE during their undergraduate eduation [6].

In addition, the characteristics of the respondents who are all final year students can also play a role in the forming positive perceptions of IPE. This is in line with study of Al-qahtani about healthcare students attitude toward interprofessional education, where there is the positive significant relationships betweenthe year of study and the overall The Readiness for Interprofesional Learning Scale (RIPLS) score, teamworkand collaboration subscale score, and negativeprofessional identity subscale score indicated that seniorstudents were more likely than junior students to have positive attitudes toward interprofessional learning [6].

Another study conducted by Ayala about the perceptions of IPE in medical students confirmed that the degree of exposure to IPE differed greatly by class year with only $38.6 \%$ of students in year 1 reporting prior experience with IPE. However by year 4, $92.9 \%$ of students reported experience in one or more of these settings [8].

Based on the data analysis of the score of the IPE component from the answers of each respondent showed the average results in good categories, but there were several low answer scores from the scores of each IPE component of each respondent. Comparison of the component of IPE by discipline is useful in understanding views and attitudes that may be 
characteristic of the spesific discipline and may provide an explanation for the differences observed between the disciplines [9].

Respondentsanswers from students of medical education study program on the perception of IPE on all components were good, the average score was $61.9(86 \%)$ with an average scoreof competency and autonomy component of 25.30 (84\%), perceived need for cooperation was $10.09(84 \%)$ and perceptions of actual cooperation was $26.57(89 \%)$.

Respondentsanswers from students of nursing science concentration towards perceptions of IPE in all components is good, the average score was $61.6(86 \%)$. Based on the perceptions of each component of the IPE, the average scores of competency and autonomy component was $25.43(85 \%)$, the component of perceived need for cooperation was $9.00(75 \%)$ and perceptions of actual cooperation at $27.17(91 \%)$.

Based on the results of the classification of IPE component scores, it shows that the understanding of students of the medical education study program about competency and autonomy is lower than nursing science students, understanding about perceived need for cooperation is higher than students in nursing science, and understanding of perceptions of actual cooperation is lower from nursing science students.

This finding is in line with the research conducted by Judge et al. about receptiveness and response to an interprofessional learning activity across health care disciplines show that medicine scoring lowest among the disciplines. This can be caused by lack of information and training about IPE that obtained by medical students compare to other health students. Besides that, because they are educated in the medical model, there might be something about students who influences their opinion on the value of working with other health care professions students on a team. So, given this impact, particular focus is necessary when planning interprofessional learning activities to ensure equal engagement among disciplines [9].

The results of this study are in line with the research conducted by Hakiman et al, there are respondents who have poor perceptions on the components of perceived need for professional cooperation, while those in the other two components do not exist. This shows that students' understanding of the components of perceived need for professional cooperation is lower compared to the other two components [1]. The other finding by Khajehghyasi et al. showed that the significant difference was observed in the competency and authority component $(\mathrm{p}=0.039)$. The mean of competency and authority component (among faculty members) had more members with interprofessional education experience [2].

Based on the results of the different test Mann Withney obtained $p$ value $=0.097$ with a significant value $p>0.05$, so it can be concluded that there is no difference in perceptions of the Medical Faculty Students of Halu Oleo University about Interprofessional Education. This finding contradicts the result of A'la research on student perception and readiness of academic stage toward Interprofessional Education at the Faculty of Medicine, Gadjah Mada University". Tests on two study programs are medical education study program and nursing science study program showed differences perception, with the results of different tests $p$ value $=0.006[10]$.

So, it is necessary to implement learning methods about the IPE so that students understand more about IPE and can create learning processes in good collaboration between professions, both in the academic stage and at the professional stage. Beside that, identification of factors influencing readiness for interprofessional learning are key to developing learning strategies targeted to improve teamwork, quality of care and patients outcomes [9]. 


\section{Conclusions}

Medical Education Study Program students of Medical Faculty of Halu Oleo University have good perceptions, both on all components and on each component of the IPE. Student of Nursing Science Concentration of Medical Faculty of Halu Oleo University have good perceptions too, both on all components and on each component of the IPE.

There were no difference in perceptions about IPE of the Medical Education Study Program Students and students in the Nursing Science Concentration at the Medical Faculty of Halu Oleo University, which means that both study programs had a good perception of the IPE.Therefore, there is a need for an introduction to IPE at the academic stage in Medical Faculty students of Halu Oleo University and also need to do futher research on IPE in other heath study program at Halu Oleo University.

Acknowledgements. I wish to thank all participating students for their valuable collaboration in this study.

\section{References}

[1] Hakiman, Assisca, dkk. Persepsi Mahasiswa Profesi Kesehatan Universitas Padjajaran Terhadap Interprofessionalisme Educatin. Fakultas Kedokteran. UNPAD, 2016.

[2] Khajehghyasi, R. V., Ebrahim, S., Jafari, M., \& Shahbaznejad, s L.: A Survey of the Perception of Interprofessional Education among Faculty Members of Mazandaran $\begin{array}{lllll}\text { University } & \text { of } & \text { Medical } & \text { Sciences }\end{array}$ https://doi.org/10.5812/sdme.64086.Research

[3] Israbiyah, S. R. Persepsi Mahasiswa tentang Interprofessional Education di Universitas Muslim Surakarta. Fakultas Kesehatan Prodi Ilmu Kesehatan. Surakarta, 2016.

[4] Mahler, C., Schwarzbeck, V., Mink, J., \& Goetz, K. Students ' perception of interprofessional education in the bachelor programme " Interprofessional Health Care " in Heidelberg, Germany: an exploratory case study, 1-8, 2018. https://doi.org/10.1186/s12909-018-1124-3

[5] Vaughan, B., Macfarlane, C., Dentry, T., \& Mendoza, G. The Interdisciplinary Education Perception Scale ( IEPS ): which factor structure? The Interdisciplinary Education Perception Scale (IEPS): which factor structure?, (February 2016), 2014. https://doi.org/10.5959/eimj.v6i3.259

[6] Al-qahtani, M. F. Measuring healthcare students ' attitudes toward interprofessional education. Journal of Taibah University Medical Sciences, 11(6), 579-585, 2016. https://doi.org/10.1016/j.jtumed.2016.09.003

[7] Vaughan, B. Measurement Properties of the Interdisciplinary Education Perception Scale in an Australian Allied Health Student Cohort. Health Professions Education, 1-6, 2018. https://doi.org/10.1016/j.hpe.2018.07.005

[8] Ayala, N., \& Macdonnell, C. P. A Cross-Sectional Analysis of Perceptions of Interprofessional Education in Medical Students, 20, 6-9, 2014. https://doi.org/10.1007/BF03355285

[9] Judge, M. P., Polifroni, E. C., Maruca, A. T., Hobson, M. E., Leschak, A., \& Zakewicz, H. Science Direct Evaluation of students â€TM receptiveness and response to an interprofessional learning activity across health care disciplines: An approach toward team development in healthcare, 2, 5-10, 2014. https://doi.org/10.1016/j.ijnss.2015.01.003

[10] A'la, Muhammad Z., Mariyono S., Totok Harjanto, Martina Sinta K. Persepsi dan 
Kesiapan Mahasiswa Tahap Akademik Terhadap Interprofessional Education Di Fakultas Kedokteran Universitas Gadjah Mada. Fakultas Ilmu Kesehatan UGM. Yogyakarta, 2012. 